\title{
The Effect of Chloramphenicol on the Growth of Scenedesmus quadricauda
}

\author{
By F. J. TAYLOR \\ Department of Botany, University College of Sierra Leone
}

(Received 10 December 1964)

\begin{abstract}
SUMMARY
The effects of different concentrations of $\mathrm{D}(-)$ threo and $\mathrm{L}(+)$ threochloramphenicol on the growth of Scenedesmus quadricauda have been studied. The results indicate: $(a)$ both isomers caused an increase in the total population largely independent of concentration; $(b)$ at concentrations between 100-200 $\mu \mathrm{g}$. $/ \mathrm{ml}$. both isomers gave a secondary increase in growth after a secondary lag period of 4-6 days; $(c)$ both isomers inhibited the growth rate at concentrations comparable with those which inhibit bacterial growth and protein synthesis. The $\mathbf{L}(+)$ threo isomer was twice as effective as the $\mathrm{D}(-)$ threo isomer, though it did not give any inhibition below $22 \mu \mathrm{g} . / \mathrm{ml}$. $(d)$ above $50 \mu \mathrm{g} . / \mathrm{ml}$. the $\mathbf{D}(-)$ threo isomer gave a significantly greater lag period than below this concentration. The $\mathrm{L}(+)$ threo isomer did not affect the lag period below $25 \mu \mathrm{g} . / \mathrm{ml}$. , but above this concentration, an increase in the concentration lengthened the lag period at the same rate as with the $\mathrm{D}(-)$ threo isomer above $50 \mu \mathrm{g} . / \mathrm{ml}$.
\end{abstract}

\section{INTRODUCTION}

Chloramphenicol has been shown to inhibit the growth of bacteria, and its mode of action is thought to be by inhibition of protein synthesis (Brock, 1961). Lacks $\&$ Gros (1960) found that the initial rate of incorporation of radioactive amino acids into RNA in Escherichia coli was decreased by $80 \%$ with, for instance, chloramphenicol $20 \mu \mathrm{g} . / \mathrm{ml}$. Concentrations of this order do not affect respiration. In higher plant tissues, chloramphenicol inhibits other physiological processes, e.g. ion accumulation in beetroot slices and carrot roots (Sutcliffe, 1960), and calcium binding in maize mitochondria (Hanson \& Hodges, 1963), though at concentrations 40-100 times greater than those which inhibit protein synthesis in bacteria. Although these inhibitions have been ascribed to inhibition of protein synthesis and Jacoby \& Sutcliffe (1962) have shown that protein synthesis is inhibited in beetroot slices at these concentrations, Hanson \& Hodges (1963) and Stoner, Hodges \& Hanson (1964) showed that the calcium binding in maize mitochondria was inhibited under conditions where no net protein synthesis was to be expected. They further noted that the effect of chloramphenicol was much like that of the uncoupling agent 2,4-dinitrophenol, and showed that chloramphenicol at $0.8-1.6 \mathrm{mg} . / \mathrm{ml}$., decreased the $\mathrm{P} / \mathrm{O}$ ratio very considerably. They thought that observations such as those of Jacoby \& Sutcliffe (1962) might be secondary effects due primarily to the uncoupling of oxidative phosphorylation. Ellis (1963) reported that when precautions were taken to overcome the inhibition of amino acid uptake in beetroot slices, there was no chloramphenicol inhibition of $\mathrm{L}$-leucine and $\mathrm{L}$-threonine incorporation 
into the trichloroacetic acid-insoluble fraction, although salt uptake was still inhibited.

The effect of chloramphenicol on the growth of micro-organisms other than bacteria has been somewhat neglected, because most of them appeared to be insensitive, though this may have been because in some cases at least, too small concentrations were used. Mager (1960) reported that the growth of Tetrahymena pyriformis was 'considerably delayed or completely arrested at $25-150 \mu \mathrm{g} . / \mathrm{ml}$.' without saying whether this referred to the lag phase, or to the growth rate.

Vazquez (1964) stated that no effect of chloramphenicol has been obtained on the growth of green plants but Tamiya, Morimura \& Yokota (1962) showed that the growth rate of the green alga Chlorella ellipsoidea was affected by chloramphenicol 300-3000 $\mu \mathrm{g} . / \mathrm{ml}$. but not by $30 \mu \mathrm{g} . / \mathrm{ml}$. Although growth was completely suppressed at the highest concentration, cell division occurred once, at the same time as in cells in a control culture, but gave extremely small daughter cells which were incapable of further growth when transferred to the normal culture medium. Kumar (1963) found that the maximum concentration of chloramphenicol which permitted growth of the blue-green alga Anacystis nidulans was $6 \mu \mathrm{g} . / \mathrm{ml}$.; over the range 1-6 $\mu \mathrm{g} . / \mathrm{ml}$. there was no effect on the growth rate, but with higher chloramphenicol concentrations there was an increase in the lag period. However, he did not prolong incubation of his cultures at the higher concentrations beyond 12 days.

Thus the green alga Chlorella ellipsoidea appears to be affected by chloramphenicol at concentrations similar to those which affect the higher plants, but Anacystis nidulans is as sensitive as the bacteria. It may be significant that Echlin (1964) said that this alga showed, under the electron microscope, structural features which previously had only been associated with bacteria. The experiments reported below were done as a preliminary to other work on the effect of chloramphenicol on metabolic processes in Scenedesmus quadricauda; they showed that this green alga has a sensitivity to chloramphenicol of the same order as that of bacteria, and considerably higher than that of Chlorella from which, systematically, it is not far removed.

\section{METHODS}

Organism. Scenedesmus quadricauda (Turp.) Breb., originally isolated by Professor W. Rodhe (Uppsala, Sweden) and obtained from the culture collection of algae at the Plant Physiological Institute, University of Göttingen, Western Germany, as strain 276/4 C, through the courtesy of Professor A. Pirson.

Cultivation. The culture solution was Österlind's (1949) solution C, which contains sodium carbonate as a $\mathrm{CO}_{2}$ source; $25 \mathrm{ml}$. culture medium was contained in $100 \mathrm{ml}$. conical flasks. The cultures were grown at $25^{\circ}$ under continuous fluorescent lighting from below. The light intensity was 4500 lux at the level of the culture, which was a light-saturating intensity for growth under these conditions. The cultures were shaken twice a day.

Chemicals. D (-) threo-chloramphenicol was obtained from Parke Davis and Co. (Hounslow, Middlesex, England) who also provided the sample of $L(+)$ threochloramphenicol. The chloramphenicol solutions were sterilized by Seitz filtration, and added to culture media after these had been autoclaved. 
Coenobial counts. A sample $(0 \cdot 25 \mathrm{ml}$.) was removed on each occasion for counting coenobia in a haemocytometer. The small percentage of coenobia with fewer or more cells than four were adjusted to four-celled coenobia.

Lag periods. The coenobial counts were plotted as log. coenobial numbers $/ \mathrm{mm}^{\mathbf{3}}$ against time, and the primary lag periods were calculated to the nearest 0.25 day from the time of inoculation to the intercept of the calculated logarithmic growth line on the mean lag population. The secondary lag periods were calculated in a similar way from the intercepts of the two logarithmic growth lines on the mean stationary population.

Growth rates. Both primary and secondary growth rates were calculated as the coefficient $b$ in the formula: $\log . N=a+b t$, which is the regression line of log. coenobial numbers/unit volume $(N)$ on time ( $t$ in days). They are thus estimates of the specific growth rates.

\section{RESULTS}

\section{Effect of $\mathrm{D}(-)$ threo-chloramphenicol on growth}

A series of cultures were set up at $\mathbf{D}(-)$ chloramphenicol concentrations from $\mathbf{0} \cdot \mathbf{1}-$ $200 \mu \mathrm{g} . / \mathrm{ml}$. Illustrative curves are shown in Fig. 1, and the relevant data extracted from the whole series in Table 1. First of all, an effect can be seen on the total population. There were no statistically significant differences between the total

Table 1. Effect of $\mathrm{D}(-)$ threo-chloramphenicol concentration on growth of Scenedesmus quadricauda

\begin{tabular}{|c|c|c|c|c|c|c|}
\hline $\begin{array}{l}\text { Chloram- } \\
\text { phenicol } \\
\text { con- } \\
\text { centration } \\
(\mu \mathrm{g} . / \mathrm{ml} .)\end{array}$ & $\begin{array}{c}\text { Primary } \\
\text { growth } \\
\text { rate* }\end{array}$ & $\begin{array}{c}\text { Secondary } \\
\text { growth } \\
\text { rate* }\end{array}$ & $\begin{array}{l}\text { Primary } \\
\text { lag } \\
\text { period } \\
\text { (days) }\end{array}$ & $\begin{array}{c}\text { Secondary } \\
\text { lag } \\
\text { period } \\
\text { (days) }\end{array}$ & $\begin{array}{c}\text { Primary } \\
\text { maximum } \\
\text { population } \\
\text { (coenobia/ } \\
\text { mm. }{ }^{3} \text { ) }\end{array}$ & $\begin{array}{c}\text { Secondary } \\
\text { maximum } \\
\text { population } \\
\text { (coenobia/ } \\
\text { mm. }\end{array}$ \\
\hline 0 & 0.59 & - & 0 & . & $596 \pm 37$ & . \\
\hline $0 \cdot 1$ & 0.51 & . & 0 & . & $752 \pm 60$ & . \\
\hline 1 & $0 \cdot 37$ & . & $1 \cdot 5$ & . & $768 \pm 69$ & . \\
\hline 5 & $0 \cdot 32$ & . & $5 \cdot 0$ & . & $758 \pm 44$ & . \\
\hline 10 & $0 \cdot 30$ & . & $5 \cdot 5$ & . & $742 \pm 39$ & . \\
\hline 25 & $0 \cdot 26$ & . & $7 \cdot 5$ & . & $692 \pm 36$ & . \\
\hline 50 & $0 \cdot 20$ & . & $9 \cdot 0$ & . & $717 \pm 41$ & . \\
\hline 100 & $0 \cdot 17$ & 0.06 & $15 \cdot 75$ & 4.5 & $698 \pm 43$ & $1638 \pm 72$ \\
\hline 150 & $0 \cdot 14$ & 0.05 & $18 \cdot 5$ & $4 \cdot 0$ & $734 \pm 42$ & $1748 \pm 98$ \\
\hline 200 & $0 \cdot 14$ & $0 \cdot 04$ & $23 \cdot 25$ & $5 \cdot 75$ & $867 \pm 51$ & $1642 \pm 85$ \\
\hline
\end{tabular}

* Growth rate calculated as coefficient $b$ in formula $\log N=a+b t$, which is regression line of log. coenobial numbers/unit volume $(N)$ on time ( $t$ in days).

populations from chloramphenicol derivative $0 \cdot 1-150 \mu \mathrm{g} . / \mathrm{ml}$., but all these showed statistically significant increases over the control. The culture at $200 \mu \mathrm{g} . / \mathrm{ml}$. showed a further statistically significant increase over the $150 \mu \mathrm{g} . / \mathrm{ml}$. culture. Moreover, at $100 \mu \mathrm{g} . / \mathrm{ml}$. and above, after a second lag period, further growth took place, though at a much lower rate than during the original increase, giving a final population which was roughly double that of the first stationary phase. There was also a change in behaviour in the duration of the primary lag period above $50 \mu \mathrm{g} . / \mathrm{ml}$. Above this concentration the lag period was considerably shorter than would have been expected from the values at the lower concentrations. When the length of the 
lag period was plotted against log. chloramphenicol concentration (Fig. 2) there was a clear discontinuity. Both parts of the curve showed high correlation coefficients between the duration of the lag and log. chloramphenicol concentration.

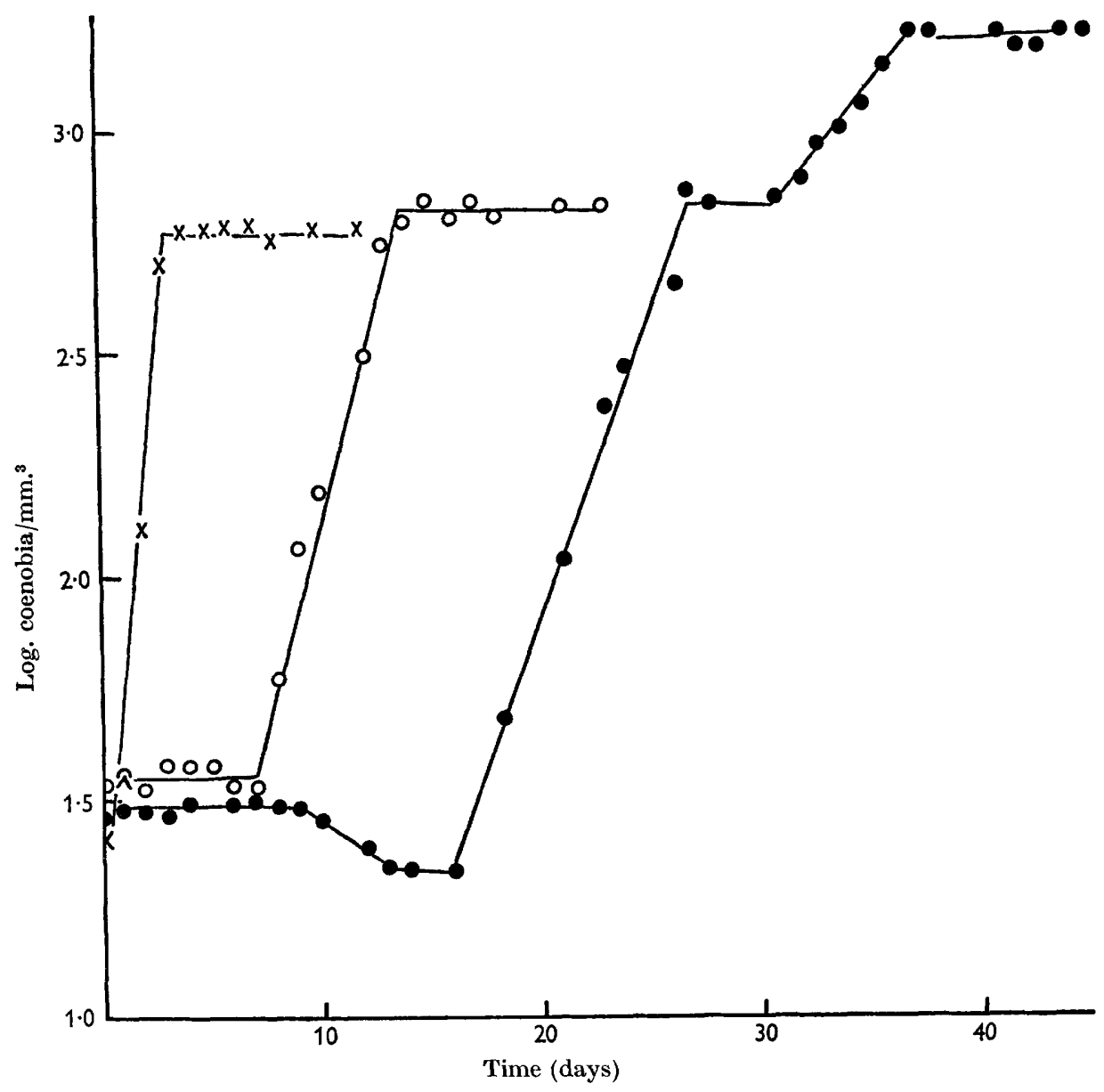

Fig. 1. Effect of $\mathrm{D}(-)$ threo-chloramphenicol at 25 and $100 \mu \mathrm{g} . / \mathrm{ml}$. on growth (coenobia $/ \mathrm{mm}^{3}$ ). of Scenedesmus quadricauda. Control, crosses; $25 \mu \mathrm{g} . / \mathrm{ml}$., open circles; $100 \mu \mathrm{g} . / \mathrm{ml}$., closed circles.

The two regression lines of lag period on log. chloramphenicol concentration have been calculated:

Below $50 \mu \mathrm{g} . / \mathrm{ml}$.:

correlation coefficient $+\mathbf{0 . 9 7}$ (significant at $P=0.01$ ), regression line $y=\mathbf{3} \cdot 36 x+\mathbf{2} \cdot 64$;

above $50 \mu \mathrm{g} . / \mathrm{ml}$.:

correlation coefficient +0.95 (significant at $P=0.05$ ), regression line $y=\mathbf{2 5} \cdot 5 x-34 \cdot 85$.

The difference between the two coefficients of $x$ is significant at $\boldsymbol{P}=\mathbf{0} \cdot 001$. 
Correlated with these differences in overall physiological behaviour at higher and lower D (-) chloramphenicol concentrations were differences in the appearances of the organisms. At $50 \mu \mathrm{g} . / \mathrm{ml}$. and below the $\mathrm{D}(-)$ chloramphenicol-treated organisms were normal in appearance and size. At $100 \mu \mathrm{g} . / \mathrm{ml}$. and above coenobia during logarithmic growth tended to clump in groups of up to 16 coenobia. These groups were frequently in fours and contained an empty coenobium, suggesting that after liberation the daughter coenobia were prevented from dispersion, possibly by an excessive production of mucilage.

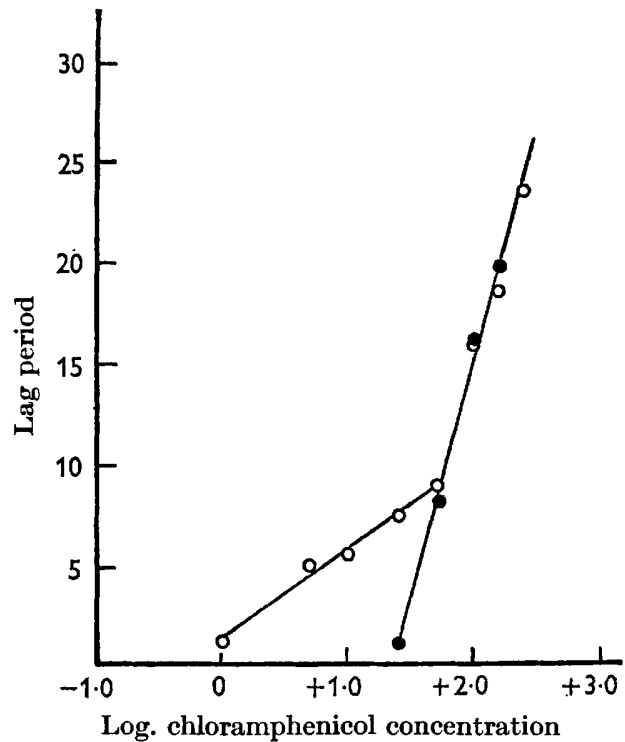

Fig. 2

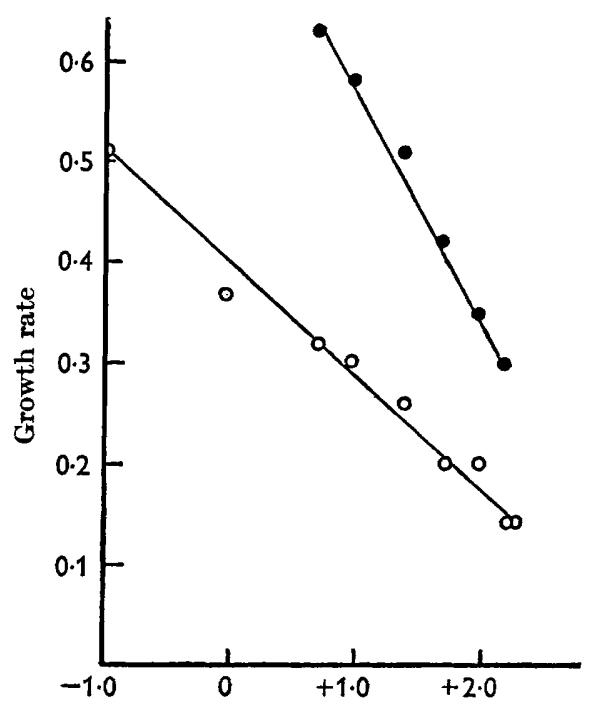

Log. chloramphenicol concentration

Fig. 3

Fig. 2. Relationship of lag period and chloramphenicol derivative concentration. Open symbols D ( - ) threo-chloramphenicol; closed symbols L $(+)$ threo-chloramphenicol. No lag period observed below $1 \mu \mathrm{g} . / \mathrm{ml}$. D (-) threo-chloramphenicol and $25 \mu \mathrm{g} . / \mathrm{ml}$. L (+) threo-chloramphenicol.

Fig. 3. Relationship of growth rate and chloramphenicol derivative concentration. Open symbols $\mathbf{D}(-)$ threo-chloramphenicol; closed symbols $\mathbf{L}(+)$ threo-chloramphenicol. Control growth rate with $\mathbf{D}(-)$ threo-chloramphenicol $=0.59$; control growth rate with $\mathbf{L}(+)$ threo-chloramphenicol $=0 \cdot 62$.

During the lag phase at these higher concentrations all the cells slowly became disorganized. The extent to which disorganization took place was very variable from cell to cell, even within the same coenobium. The first signs were a contraction of the protoplasts, disappearance of chlorophyll and disintegration of the chloroplasts. However, about 3 days before logarithmic growth began, by which time all the cells were disorganized to a greater or lesser extent (30-60\% completely empty) signs of rejuvenescence appeared in some of the cells. Single cells in a coenobium (more than two in one coenobium were not seen) showed an expansion of the protoplast and a redevelopment of chlorophyll. These rejuvenated cells then began to multiply. These disorganized coenobia were included in the coenobial counts during the lag period, but not during logarithmic growth. Completely empty coenobia 
were not counted; this accounts for the apparent decrease in numbers towards the end of the primary lag period with $\mathrm{D}(-)$ chloramphenicol $150 \mu \mathrm{g} . / \mathrm{ml}$. in Fig. 1.

The growth rate was also affected by the chloramphenicol concentration, but did not show a discontinuity (Fig. 3). Over the whole range of concentration there was a very high negative correlation between the growth rate and the log. chloramphenicol concentration $(-0.99$, significant at $P=0.01)$. The regression line of growth rate on log. chloramphenicol concentration was determined as:

$$
y=0 \cdot 40-0 \cdot 11 x \text {. }
$$

\section{Effect of D (-) threo-chloramphenicol on the growth of coenobia previously grown in $\mathrm{D}(-)$ threo-chloramphenicol $25 \mu \mathrm{g} . / \mathrm{ml}$.}

A series was set up with inocula of coenobia which had reached the stationary phase of growth in $\mathrm{D}(-)$ chloramphenicol $25 \mu \mathrm{g} . / \mathrm{ml}$. There were no statistically significant differences in behaviour as compared with the previous experiment beyond the fact that the control (i.e. inoculum grown in $\mathrm{D}(-)$ chloramphenicol $25 \mu \mathrm{g} . / \mathrm{ml}$. but inoculated into chloramphenicol-free medium) produced the same maximum population $(720 \pm 49)$ as did chloramphenicol-treated organisms. The growth rate in this flask was also lower than in the first experiment $(0 \cdot 49)$. These results are consistent with the effect to be expected from the chloramphenicol carried over in the inoculum. This, if none had been absorbed by the organisms in the original culture, would have given a concentration of chloramphenicol 0.5 $\mu \mathrm{g} . / \mathrm{ml}$. In practice it would be somewhat lower than this. There was thus no obvious immediate adaptation of the organism to tolerate chloramphenicol.

\section{Effect of $\mathrm{I}(+)$ threo-chloramphenicol on growth}

The $\mathrm{L}(+)$ threo isomer of chloramphenicol is not antibacterial, and is much less active than the $\mathbf{D}(-)$ threo isomer as an inhibitor of amino acid incorporation into protein (Rendi \& Ochoa, 1962). Ellis (1963) however, found it to be $65-115 \%$ as effective as the $\mathrm{D}(-)$ threo isomer in inhibiting sulphate uptake of plant tissue slices, the degree of inhibition depending upon the species and chloramphenicol concentration. A similar series to the first experiment was done with $\mathrm{L}(+)$ threochloramphenicol. Typical results are shown in Fig. 4, and the extracted data in Table 2. The general effect was much the same as with $\mathbf{D}(-)$ threo-chloramphenicol, though the $\mathrm{L}(+)$ isomer did not manifest its effects at such low concentrations, and there were significant quantitative differences.

$\mathrm{Up}$ to $\mathrm{L}(+)$ isomer $50 \mu \mathrm{g} . / \mathrm{ml}$. the effect on the maximum coenobial population is the same as with the $\mathrm{D}(-)$ isomer, and there were no statistical differences between the maximum populations at corresponding concentrations up to this value. At 100 and $150 \mu \mathrm{g} . / \mathrm{ml}$. the primary population was significantly increased to an even greater extent than with $\mathrm{D}(-)$ threo-chloramphenicol $200 \mu \mathrm{g} . / \mathrm{ml}$. These two highest concentrations also show the same secondary growth effect as was observed with the $\mathrm{D}(-)$ threo isomer at these concentrations and to the same extent (a doubling of the population), but the final to+al population was very much greater with the $\mathrm{L}(+)$ threo isomer.

A plot of the lag period against log. concentration (Fig. 2) did not show the discontinuity observed with the $\mathrm{D}(-)$ isomer, and no lag was observed at $10 \mu \mathrm{g} . / \mathrm{ml}$. 


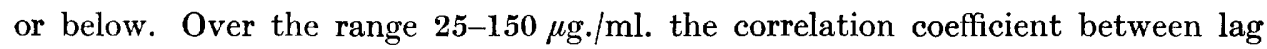
duration and log. chloramphenicol concentration was +0.99 , significant at $\boldsymbol{P}=0.001$, and the regression line of lag period on log. chloramphenicol concentration was: $y=23 \cdot 5 x-31 \cdot 47$. There were no statistically significant differences between the

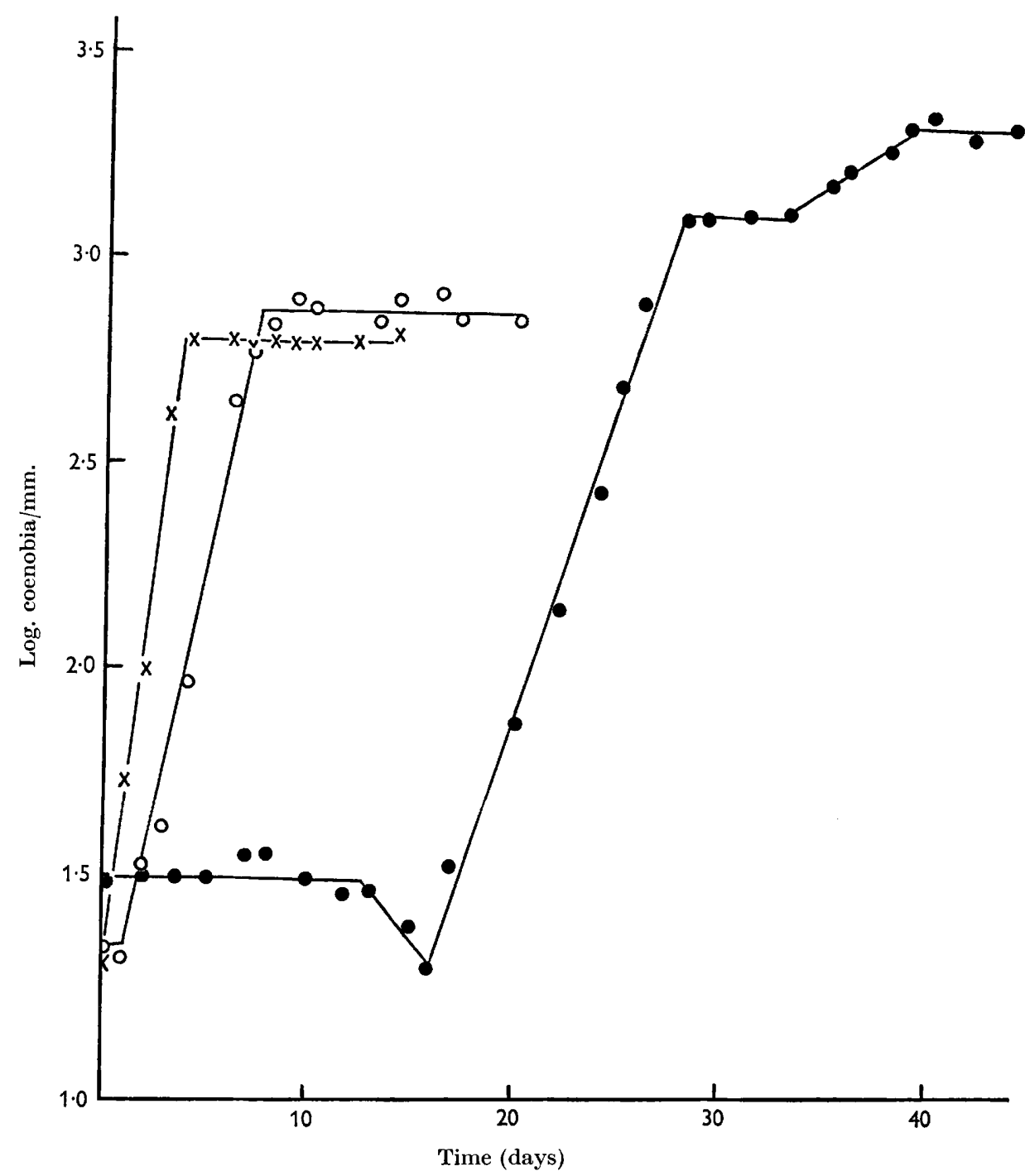

Fig. 4. Effect of $\mathrm{L}(+)$ threo-chloramphenicol at 25 and $100 \mu \mathrm{g} . / \mathrm{ml}$. on growth (coenobia/ $\mathrm{mm}^{3}$ ) of Scenedesmus quadriacauda. Control, crosses; $25 \mu \mathrm{g} . / \mathrm{ml}$., open circles; 100 $\mu \mathrm{g} . / \mathrm{ml} .$, closed circles.

coefficients of $x$ or the constants in the regression lines for the $\mathrm{L}(+)$ isomer and the upper range of the $\mathrm{D}(-)$ isomer. We may therefore conclude that the two sets of points fall on the same line, and that both isomers affect the lag period through their effect on the same process and to the same extent. However, the $\mathrm{D}(-)$ isomer also affected the lag period through another process, which was unaffected by the $\mathrm{L}(+)$ 
isomer. The degree of inhibition of this second process by the $\mathrm{D}(-)$ isomer was relatively greater than the inhibition of the first at concentrations lower than $50 \mu \mathrm{g} . / \mathrm{ml}$., but the relative inhibitions were reversed above this concentration.

The $\mathrm{L}(+)$ isomer had similar effects to the $\mathrm{D}(-)$ isomer on the cellular morphology at $50 \mu \mathrm{g} . / \mathrm{ml}$. and above.

Table 2. Effect of $\mathrm{L}(+)$ threo-chloramphenicol concentration on growth of Scenedesmus quadricauda

\begin{tabular}{|c|c|c|c|c|c|c|}
\hline $\begin{array}{l}\text { Chloram- } \\
\text { phenicol } \\
\text { con- } \\
\text { centration } \\
(\mu \mathrm{g} . / \mathrm{ml} .)\end{array}$ & $\begin{array}{c}\text { Primary } \\
\text { growth } \\
\text { rate* }\end{array}$ & $\begin{array}{l}\text { Secondary } \\
\text { growth } \\
\text { rate* }\end{array}$ & $\begin{array}{l}\text { Primary } \\
\text { lag } \\
\text { period } \\
\text { (days) }\end{array}$ & $\begin{array}{c}\text { Secondary } \\
\text { lag } \\
\text { period } \\
\text { (days) }\end{array}$ & $\begin{array}{l}\text { Primary } \\
\text { maximum } \\
\text { population } \\
\text { (coenobia/ } \\
\text { mm. }{ }^{3} \text { ) }\end{array}$ & $\begin{array}{c}\text { Secondary } \\
\text { maximum } \\
\text { population } \\
(\text { coenobia/ } \\
\left.\text { mm. } .^{3}\right)\end{array}$ \\
\hline 0 & 0.62 & . & 0 & . & $648 \pm 31$ & . \\
\hline 1 & 0.61 & . & 0 & . & $752 \pm 45$ & . \\
\hline 5 & 0.63 & . & 0 & . & $709 \pm 49$ & . \\
\hline 10 & 0.58 & . & 0 & . & $774 \pm 42$ & . \\
\hline 25 & 0.51 & . & $1 \cdot 25$ & . & $754 \pm 47$ & . \\
\hline 50 & 0.42 & . & $8 \cdot 0$ & . & $748 \pm 39$ & . \\
\hline 100 & $0 \cdot 35$ & 0.07 & $16 \cdot 25$ & $4 \cdot 5$ & $1292 \pm 53$ & $2252 \pm 61$ \\
\hline 150 & $0 \cdot 30$ & 0.06 & $19 \cdot 75$ & $5 \cdot 25$ & $1304 \pm 71$ & $2212 \pm 159$ \\
\hline
\end{tabular}

* Growth rate calculated as coefficient $b$ in formula $\log N=a+b t$, which is regression line of log. coenobial numbers/unit volume $(N)$ on time ( $t$ in days).

The effect of $L(+)$ threo-chloramphenicol on the growth rate showed a very high negative correlation between growth rate and the log. chloramphenicol concentration ( -0.999 ; Fig. 3$)$; and the regression line of growth rate on log. chloramphenicol concentration was: $y=0 \cdot 81-0.23 x$. The coefficient of $x$ for the $\mathrm{L}(+)$ isomer was twice that of the corresponding coefficient for the $\mathrm{D}(-)$ isomer; the difference was statistically significant $(P=0 \cdot 01)$. The two regression lines cut the ordinate at $x=3.63(\mathrm{D}(-))$ and $3.53(\mathrm{~L}(+))$. The standard error of estimate of $x$ for the $\mathrm{D}(-)$ isomer was $1.8 \%$. Since the value of $x$ when $y=0$ for the $\mathrm{L}(+)$ isomer differed from the value for the $\mathrm{D}(-)$ isomer by less than twice this standard error, we can conclude that if both regression lines were extrapolated to the ordinate, they would cut it at the same point. In other words the concentrations of both isomers necessary for complete theoretical inhibition are the same. It seems likely therefore, that they both act on the same process, but at different rates. The $\mathbf{L}(+)$ isomer was twice as effective an inhibitor as the $\mathrm{D}(-)$ though it only began to inhibit at a higher concentration, possibly through differences in permeability.

\section{DISCUSSION}

Although Scenedesmus quadricauda is an autotrophic organism, the kinetics of its growth can be treated like those of the bacteria (Hinshelwood, 1946). Its considerably longer growth period, though, does not make it such a convenient organism for extended studies of adaptation. The increase in total population on treatment with the chloramphenicol derivatives suggests that nutrient exhaustion was not the factor causing the cessation of normal logarithmic growth. The limiting factor appears to be the $\mathrm{pH}$ of the medium, a $\mathrm{pH}$ of 12 coinciding with the cessation of growth in 
normal cultures. The cessation of growth in chloramphenicol cultures below $100 \mu \mathrm{g} . / \mathrm{ml}$. was found to cease when the $\mathrm{pH}$ was between 10 and 11 . By lowering the $\mathrm{pH}$ of a control culture in the stationary phase it was found possible to increase the population from $581 \pm 45$ and $780 \pm 53$. It is possible, therefore, to account for the increase in population with chloramphenicol to a delay in the attainment of an adverse $\mathrm{pH}$. This might be effected through differences in the relative rates of inhibition of cation and anion uptake. Hinshelwood (1946, p. 72) has noted that the influence of $\mathrm{pH}$ upon total population in bacterial cultures consists largely of changing the limiting factor from exhaustion of foodstuff to accumulation of inhibitors. We have no experimental evidence for the occurrence of any external inhibitors beyond the hydroxyl ion (if in fact it is this aspect of $\mathrm{pH}$ which limits growth).

The pattern of response of total population at $100 \mu \mathrm{g} . / \mathrm{ml}$. and above is reminiscent of the phenomenon of diauxie (Monod, 1942). However, in the case of Scenedesmus there does not appear to be a second source of nutrition unless it be the chloramphenicol itself, which appears unlikely. Moreover, the phenomenon has appeared in some experiments without chloramphenicol, under growth-limiting light conditions, and the phenomenon merits further investigation. We may note, however, that under certain experimental conditions (which are not obtained in these chloramphenicol experiments), Scenedesmus cells are capable of releasing considerable amounts of carbohydrate into the medium, which could conceivably act as an energy-source.

The possibility that this secondary increase is an artefact due to the prolonged sampling, and consequent lowering of the culture volume, was considered, but since no secondary increase was observed after the same number of samples had been taken from a $25 \mu \mathrm{g} . / \mathrm{ml}$. culture, and since it took place later with the $200 \mu \mathrm{g} . / \mathrm{ml}$. culture than with the $100 \mu \mathrm{g} . / \mathrm{ml}$. culture, though both were sampled on the same occasions, the effect is considered real.

Woof \& Hinshelwood (1961) noted a discontinuity in the shape of the lag/ chloramphenicol concentration curve with 'Bacterium lactis aerogenes' (Aerobacter aerogenes). They favoured the explanation that chloramphenicol affected two different functions of the organisms rather than that there was a small number of pre-existing mutants resistant to the low drug concentrations but sensitive to high ones. The form of the lag/concentration curve is thought to favour a similar explanation for Scenedesmus quadricauda, with the additional support that only one of these functions was affected by the $\mathrm{L}(+)$ isomer used. Similar conclusions can be drawn from the observations of the cellular changes. No cellular disintegration was observed at concentrations below the discontinuity, but were found in all cells above, showing that there was a distinct difference in effect in the two ranges. The cells which recovered from degeneration were those statistically favoured members of the population involved in a competition between 'adaptive' and lethal processes.

Only one effect on the growth rate was observed, and the $L(+)$ isomer was twice as effective an inhibitor of this as the $\mathrm{D}(-)$ isomer. This makes it unlikely that the growth rate was limited in the treated cells by either of the processes which limit the lag period in the presence of chloramphenicol derivative.

There is a considerable difference between various organisms and tissues in the concentration at which chloramphenicol inhibitions occur. The responses of 
Scenedesmus quadricauda occur at the same order of concentration as for bacteria, as opposed to higher plant tissues and the only other green alga which has been investigated, Chlorella. These differences might be due to differences in permeability to chloramphenicol in the two groups, which might operate through differences in the proteins or lipids of the plasma membrane, or be due to differences in the site of chloramphenicol binding. Vazquez (1964) showed considerable differences in the latter as between sensitive and resistant organisms at low chloramphenicol concentrations.

I am greatly indebted to Mrs Ann Lorton for technical assistance, and to Messrs Parke Davis \& Co. for the gift of $\mathbf{L}(+)$ threo-chloramphenicol.

\section{REFERENCES}

Brock, T. D. (1961). Chloramphenicol. Bact. Rev. 25, 32.

Echurv, P. (1964). The fine structure of certain unicellular blue-green algae. Brit. phycol. Bull. 2, 389.

Elis, R. J. (1963). Chloramphenicol and uptake of salt in plants. Nature, Lond., 200, 596.

Hanson, J. B. \& Hodges, T. K. (1963). Uncoupling action of chloramphenicol as a basis for the inhibition of ion accumulation. Nature, Lond., $200,1009$.

Hinshelwood, C. N. (1946). The Chemical Kinetics of the Bacterial Cell. Oxford: Clarendon Press.

JACOBY, B. \& Sutchiffe, J. F. (1962). Effects of chloramphenicol on the uptake and incorporation of amino-acids by carrot root tissue. J. exp. Bot. 13, 335.

Kumar, H. (1963). Effects of mutagenic agents on blue-green algae. Ph.D. thesis, London University.

LACKS, S. \& Gros, F. (1960). A metabolic study of the RNA-amino acid complex in Escherichia coli. J. mol. Biol. 1, 301.

MAGER, J. (1960). Chloramphenicol and chlortetracycline inhibition of amino acid incorporation into proteins in a cell-free system from Tetrahymena pyriformis. Biochem. biophys. acta, 38, 152.

MonoD, J. (1942). Recherches sur la croissance des cultures bactériennes. Actualités scientifiques et industrielles. 911. Microbiologie. Paris: Hermann

ÖstERLIND, S. (1949). Growth conditions of the alga Scenedesmus quadricauda. Symb. bot. upsaliens 10, no. 3.

Rendi, R. \& OchoA, S. (1962). Effect of chloramphenicol on protein synthesis in cell free preparations of Escherichia coli. J. biol. Chem. 237, 3711.

Stoner, C. D., Hodges, T. K. \& Hanson, J. B. (1964). CMP as an inhibitor of energylinked processes in maize mitochondria. Nature, Lond. 203, 258.

SuTcliffe, J. F. (1960). New evidence for a relationship between ion absorption and protein turnover in plant cells. Nature, Lond. 188, 294.

TAmiYa, H., Morimura, Y. \& Yokota, M. (1962). Effect of various antimetabolites upon the life cycle of Chlorella. Arch. Mikrobiol. 42, 4.

VAZQUEz, D. (1964). Uptake and binding of chloramphenicol by sensitive and resistant organisms. Nature, Lond. 203, 257.

Woof, J. B. \& Hinshelwood, C. N. (1961). Chloramphenicol resistance of Bact. lactis aerogenes (Aerobacter aerogenes). I. Adaptive and lethal processes in liquid media and on agar plates. Proc. roy. Soc. B, 153, 321. 